\title{
OPTIMASI SUHU ANNEALING UNTUK AMPLIFIKASI GEN AKTIN PADA PANDAN (Pandanus sp)
}

\section{Optimization of Annealing Temperature for Amplification of Actin Gene in Pandan (Pandanus sp)}

\author{
Larissa Anggisti, Dewi Indriyani Roslim, Herman \\ Program S1 Biologi Bidang Genetika Jurusan Biologi \\ Fakultas Matematika dan Ilmu Pengetahuan Alam Universitas Riau \\ Email: dewiindriyaniroslim@gmail.com \\ [Diterima: April 2018; Disetujui Juli 2018]
}

\begin{abstract}
Genes expression information involved in Pandanus sp. adaptation in Kajuik Lake sp. to environmental stress is unknown. The genes expression analysis requires the internal control gene such as actin. Actin gene is one of the genes that can be expressed continuously at all stages of plant development. Before obtaining genetic information, it is necessary to isolate and amplify DNA. The purpose of this study was to determine the annealing temperature for actin gene amplification in Pandan (Pandanus sp.). The DNA amplification uses two primer pairs with 20 annealing temperatures. The annealing temperatures were calculated based on the mean values of Tm which were then reduced and added with 5, 4, 3, 2 and 1 . The annealing temperature of $53.4{ }^{\circ} \mathrm{C}(\mathrm{Tm}+1)$ yielded single thick clear using. The annealing temperature of $53.4{ }^{\circ} \mathrm{C}(\mathrm{Tm}+1)$ using P_act_F / P_act_R1 primer pair yielded single, thick and firm DNA band. It was concluded that the annealing temperature for actinin gene amplification in Pandanussp was $53.4{ }^{\circ} \mathrm{C}$ with primer P_act_F / P_act_R1.
\end{abstract}

Keywords: Actin gene, Annealing temperatures, PCR

\begin{abstract}
ABSTRAK
Informasi mengenai ekspresi gen-gen yang terlibat dalam adaptasi tumbuhan Pandanus sp. dari Danau Kajuik terhadap cekaman lingkungan belum diketahui. Untuk analisis ekspresi gen memerlukan gen referensi yang berfungsi sebagai kontrol internal, salah satunya adalah aktin. Gen aktin merupakan salah satu gen yang dapat diekspresikan secara terus-menerus pada semua tahapan perkembangan. Sebelum mendapatkan informasi ilmiah secara genetik perlu dilakukan isolasi dan amplifikasi DNA. Tujuan dari penilitian ini menentukan suhu annealing untuk amplifikasi gen aktin pada Pandan (Pandanus sp.). Amplifikasi DNA menggunakan dua primer aktinspesifik Pandanus sp. dengan 20 suhu annealing. Suhu annealing yang dioptimasi dihitung berdasarkan nilai rata-rata $\mathrm{T}_{\mathrm{m}}$ dikurangi dan ditambahkan dengan nilai 5, 4, 3, 2 dan 1. Optimasi pada suhu annealing $53.4{ }^{\circ} \mathrm{C}(\mathrm{Tm}$ +1) menggunakan pasangan primer P_act_F/P_act_R1 menghasilkan pita DNA yang tunggal, tebal dan tegas. Disimpulkan, suhu annealing untuk amplifikasi gen aktin pada Pandanus sp adalah 53.4 ${ }^{\circ} \mathrm{C}$ dengan primer P_act_F/P_act_R1.
\end{abstract}

Kata kunci: Gen aktin, Suhu annealing, PCR

\section{PENDAHULUAN}

Gen aktin merupakan salah satu gen pengendalian internal yang telah banyak digunakan dalam penelitian terkait cekaman lingkungan karena gen aktin memiliki tingkat ekspresi yang stabil pada semua tahapan perkembangan diberbagai jaringan (Chandna et al. 2012). Aktin merupakan gen yang diekspresikan terus-menerus untuk menjaga proses-proses dasar seluler (Chandna et al. 2012). Keberadaan kontrol internal dalam 
analisis ekspresi gen sangat penting serta erat hubungannya dengan interpretasi data yang dihasilkan.

Kontrol internal didalam suatu gen makhluk hidup salah satunya dapat dilakukan dengan suatu tekhnik molekuler yaitu teknik PCR (Polymerase Chain Reaction). PCR merupakansuatu metode enzimatis untuk amplifikasi DNA dengan cara in vitro.Spesifitas PCR terletak pada kemampuannya mengamplifikasi sehingga menghasilkan produk melalui sejumlah siklus. Keunggulan PCR dikatakan sangat tinggi. Hal ini didasarkan atas spesifitas, efisiensi dan keakuratan.Hasil pemeriksaan PCR dapat membantu untuk mengetahui diagnosa sepanjang pemeriksaan tersebut dikerjakan dengan cara yang benar dan sesuai dengan standar internasional(Yusuf 2010)

Teknik PCR memiliki beberapa tahapan penting, salah satunya yaitu tahap annealing (penempelan primer). Suhu annealing adalah suhu dimana primer akanmenempel pada DNA cetakan. Besarnya suhuannealing dapatdihitung berdasarkan nilai melting temperature $(\mathrm{Tm})$ dari masing-masing primer. Pencarian kondisioptimal dari suhu annealing sangat penting, karenaberkaitan dengan spesifitas dan sensitifitas produkPCR.Oleh karena itu optimasi suhu annealing perlu dilakukan terlebih dahulu untuk memperoleh produk PCR yang sesuai target.

\section{BAHAN DAN METODE}

Bahan-bahan yang digunakan pada penelitian adalah daun muda Pandanus sp., akuades, nitrogen cair, kit isolasi DNA (Qiagen, yang berisi buffer AP1, buffer P3, buffer AW1, buffer AW2, dan buffer AE), etanol absolut, akuabidestilata $\left(\mathrm{dH}_{2} \mathrm{O}\right), 10 \mathrm{X}$ TBE (Tris; boric acid; EDTA), buffer TE pH 8, komponen PCR (10X buffer PCR, 2mM dNTP, $10 \mu \mathrm{M}$ primer forward, $10 \mu \mathrm{M}$ primer reverse, $5 \mathrm{u} / \mu \mathrm{l}$ Taq DNApolimerase, $\mathrm{dH}_{2} \mathrm{O}$, DNA Pandanus sp.), $5 \mu \mathrm{g} / \mathrm{ml}$ etidium bromida dan gel agarose.

Alat-alat yang digunakan yaitu kotak plastik kecil, tabung reaksi, timbangan digital, gelas beaker, hot plate, pipet mikro ukuran 10 $\mu 1,200 \mu \mathrm{l}$ dan $1000 \mu \mathrm{l}$, tip mikro ukuran $10 \mu 1$, $200 \mu 1$ dan $1000 \mu 1$, gunting, mesin sentrifus, $\mathrm{pH}$ meter, waterbath, mesin elektroforesis, mesin PCR, kamera, kulkas/ freezer, dan UV transiluminator, mortar dan pastel.

Pengambilan sampel dari Danau Kajuik, Sungai Kampar, Kecamatan Langgam, Kabupaten Pelalawan, Provinsi Riau. Bagian tumbuhan yang diambil adalah daun yang masih muda untuk mempermudah isolasi DNA. Isolasi DNA, elektroforesis dan PCR dilaksanakan di Laboratorium Genetika, Jurusan Biologi, Fakultas Matematika dan Ilmu Pengetahuan Alam, Universitas Riau. Penelitian ini dilakukan pada pada bulan Desember 2016 - Maret 2017.

Isolasi dan elektroforesis DNA total menggunakan daun muda tumbuhan Pandanus sp. yang diambil sebanyak 0.1 gram.Isolasi DNA total menggunakan Qiagen mini kit. Molekul DNA total yang diperoleh kemudian dielektroforesis pada $1 \%$ gel agarose dalam $1 \mathrm{X}$ buffer TBE (Tris ; Boric acid ; EDTA pH 8,0) yang mengandung $5 \mu \mathrm{g} / \mu \mathrm{l}$ etidium bromida. Cetakan yang berisi gel dimasukkan ke dalam tanki elektroforesis kemudian sampel DNA yang diperiksa dimasukkan ke dalam masingmasing sumur dengan komposisi 2 ul loading dye +3 ul DNA sampel. Setelah itu divisualisasi di atas sinar ultraviolet.

Optimasi suhu annealing dilakukan menggunakan 2 pasang primer (Tabel 1):

$P$ act $F$ 5'- CAGCTTCTCCTTCATGTCTC3'(forward)

$P$ act R1 3'- ATGTTGCTATCCAAGCTGTT5 '(reverse)

$\mathrm{P}$ act $\mathrm{F}$ 5'- CAGCTTCTCCTTCATGTCTC$3^{-}$(forward)

P_act_R23'- GGCACCACACTTTCTACAAT3'(reverse).

Komponen PCRyang digunakan sebanyak $20 \mu \mathrm{l}$ (Tabel 2).Proses PCR meliputi pra-PCR pada $94^{\circ} \mathrm{C}$ selama 5 detik, diikuti 35 siklus yang terdiri dari tiga tahap yaitu: denaturasi pada suhu $94^{\circ} \mathrm{C}$ selama 45 detik, annealing disesuaikan dengan suhu masingmasing primer selama 1 menit (Tabel 1 ), dan extention dengan suhu $72^{\circ} \mathrm{C}$ selama 1 menit 30 detik. Tahapan terakhir adalah pasca PCR pada suhu $72^{\circ} \mathrm{C}$ selama 10 menit. 
Tabel 1. Kondisi optimal modifikasi suhu annealing primer aktin

\begin{tabular}{|c|c|c|c|c|c|c|c|c|c|c|c|}
\hline \multirow{2}{*}{$\begin{array}{c}\text { Pasangan } \\
\text { Primer }\end{array}$} & \multirow{2}{*}{$\begin{array}{c}\text { Rata-rata } \\
\operatorname{Tm}\left({ }^{\circ} \mathrm{C}\right)\end{array}$} & \multicolumn{10}{|c|}{$\mathrm{Ta}\left({ }^{\circ} \mathrm{C}\right)$} \\
\hline & & Tm-5 & Tm-4 & Tm-3 & Tm-2 & $\mathrm{Tm}-1$ & $\begin{array}{c}\mathrm{Tm}+ \\
5\end{array}$ & $\mathrm{Tm}+4$ & $\mathrm{Tm}+3$ & $\mathrm{Tm}+2$ & $\mathrm{Tm}+1$ \\
\hline $\begin{array}{l}\text { P_act_F/P } \\
\text { act_R1 }\end{array}$ & 52.4 & 47.4 & 48.4 & 49.4 & 50.4 & 51.4 & 57.4 & 56.4 & 55.4 & 54.4 & 53.4 \\
\hline $\begin{array}{l}\text { P_act_F/P } \\
\text { act_R2 }\end{array}$ & 52.8 & 47.8 & 48.8 & 49.8 & 50.8 & 51.8 & 57.8 & 56.8 & 55.8 & 54.8 & 53.8 \\
\hline
\end{tabular}

Tabel 2. Komponen PCR

\begin{tabular}{lcc}
\hline \multicolumn{1}{c}{ Komponen } & Konsentrasi akhir & Volume $(\boldsymbol{\mu l})$ \\
\hline $10 \mathrm{X}$ buffer PCR & $1 \mathrm{X}$ & 2 \\
$2 \mathrm{mM}$ dNTP & $0.1 \mathrm{Mm}$ & 1 \\
$10 \mu \mathrm{M}$ primer forward & $0.4 \mu \mathrm{M}$ & 0.4 \\
$10 \mu \mathrm{M}$ primer reverse & $0.4 \mu \mathrm{M}$ & 0.4 \\
$5 \mathrm{u} / \mu \mathrm{l}$ Taq polymerase & $1 \mathrm{Unit}$ & 0.2 \\
DNA Pandanus $\mathrm{sp}$. & $30 \mathrm{ng}$ & 1 \\
$\mathrm{~d} \mathrm{H}_{2} \mathrm{O}$ & - & 15 \\
\hline Total & & 20 \\
\hline
\end{tabular}

Elektroforesis produk PCR dilakukan pada $1 \%$ gel agarose dalam $1 \mathrm{X}$ buffer TBE (Tris-Borate-EDTA pH 8.0) yang mengandung $5 \mu \mathrm{g} / \mathrm{ml}$ etidium bromida sebagai pewarna pita DNA. Kemudian sampel DNA yang diperiksa dimasukkan ke dalam masing-masing sumur dengan komposisi 2 ul loading dye +3 ul DNA sampel. Setelah itu divisualisasi di bawah sinar ultraviolet.

\section{HASIL DAN PEMBAHASAN}

\section{Molekul DNA total Pandanus sp.}

Pada penelitian ini diperoleh molekul DNA total Pandanus sp. yang berukuran lebih besar dari $10.000 \mathrm{pb}$ dengan kondisi pita utuh,tidak smeardan konsentrasinya sebesar 30 $\mathrm{ng} / \mu \mathrm{l}$. Menurut Irmawati (2003) pita DNA yang tebal menunjukkan konsentrasi yang tinggi.

M

1

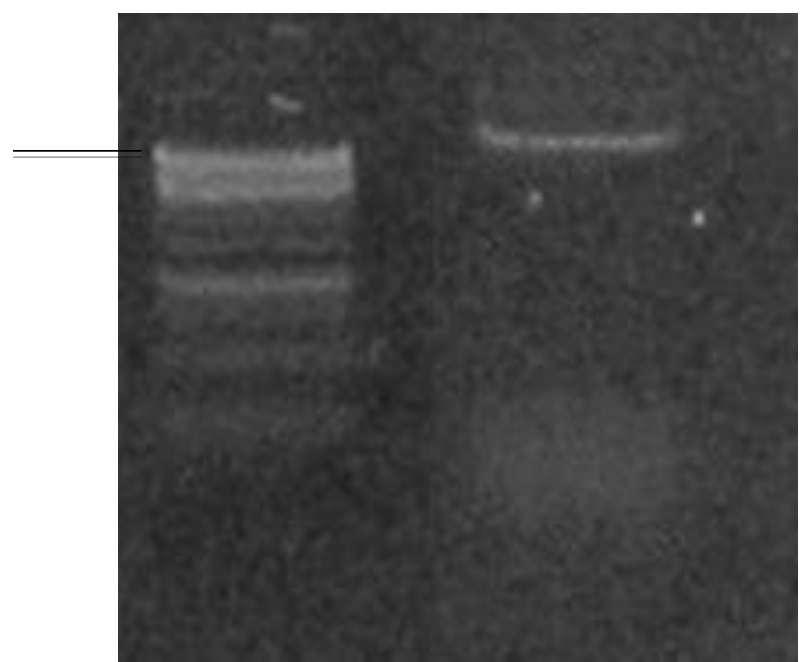

Gambar 1. Molekul DNA total Pandanus sp. Keterangan: M= $1 \mathrm{~kb}$ DNA Ladder (ThermoScientific), $1=$ DNA total Pandanus sp. dari Danau Kajuik Kabupaten Kampar). 


\section{KESIMPULAN}

Proses isolasi dari Qiagen menghasilkan DNA total yang utuh dan tidak smearyang digunakan sebagai cetakan untuk tahap amplifikasi. Suhu annealing $53.4^{\circ} \mathrm{C}$ dengan primer P_act_F/P_act_R1 merupakan suhu yang tepat untuk amplifikasi gen aktin pada Pandanus sp. yang menghasilkan pita berukuran $\pm 1200 \mathrm{pb}$.

\section{UCAPAN TERIMAKASIH}

Penulis mengucapkan terima kasih kepada DRPM-Dirjen Penguatan Riset dan Pengembangan-Kementerian Riset Teknologi dan Pendidikan Tinggi RI SIMLITABMAS DIKTI yang telah mendanai penelitian ini melalui Hibah Penelitian Fundamental tahun 2017 atas nama Dr. Dewi Indriyani Roslim, M.Si.

\section{DAFTAR PUSTAKA}

Chandna R, Augustine R, Bisht NC. 2012. Evaluation of Candidate Referenc Genes for Gene Expression Normalization in Brassica juncea Using Real Time Quantitative RT-PCR. PLOS ONE 7(5): e36918.

doi:10.1371/journal.pone.0036918.

Graham A, Newton CR. 1997. PCR(Polymerase Chain Reaction). Ed $K e-2$. New York: Springer Verlag.

Haris N, Aswidinoor H, Mathius NT, Purwantara A. 2003. Kemiripan Genetik Klon Karet (Hevea brasiliensis Muell. Arg.) Berdasarkan Metode Amplified Fragment Length Polymorphisms (AFLP). Menara Perkebunan. 71 (1) : 115.

Irmawati. 2003. Perubahan Keragaman Genetik Ikan Kerapu Tikus Generasi Pertama Pada Stok Hatchery [Tesis]. Bogor: IPB

Yusuf ZK. 2010. Polymerase Chain Reaction (PCR). Saintek 5(6): pp. 
